\title{
Eugenol as a Promising Molecule for the Treatment of Dermatitis: Antioxidant and Anti-inflammatory Activities and Its Nanoformulation
}

\author{
Amanda de Araújo Lopes, ${ }^{1}$ Francisco Noé da Fonseca, ${ }^{1}$ Talita Magalhães Rocha $\mathbb{D}^{1},{ }^{1}$ \\ Lyara Barbosa de Freitas, ${ }^{1}$ Emmanuel Vinicius Oliveira Araújo,, \\ Deysi Viviana Tenazoa Wong, ${ }^{2}$ Roberto César Pereira Lima Júnior, ${ }^{2}$ \\ and Luzia Kalyne Almeida Moreira Leal (iD ${ }^{1}$ \\ ${ }^{1}$ Pharmaceutical and Cosmetics Studies Center, Faculty of Pharmacy, Dentistry and Nursing, Federal University of Ceará, Fortaleza, \\ Ceará, Brazil \\ ${ }^{2}$ Department of Physiology and Pharmacology, Federal University of Ceará, Fortaleza, Ceará, Brazil
}

Correspondence should be addressed to Luzia Kalyne Almeida Moreira Leal; kalyneleal@gmail.com

Received 30 June 2018; Accepted 10 September 2018; Published 11 December 2018

Academic Editor: Lucindo Quintans-Júnior

Copyright (c) 2018 Amanda de Araújo Lopes et al. This is an open access article distributed under the Creative Commons Attribution License, which permits unrestricted use, distribution, and reproduction in any medium, provided the original work is properly cited.

\begin{abstract}
Contact dermatitis produces an inflammatory reaction primarily via stimulation of keratinocytes and cells of the immune system, which promote the release of cytokines, reactive oxygen species (ROS), and other chemical mediators. Eugenol (EUG, phenylpropanoid of essential oils) has attracted attention due to its anti-inflammatory properties, as well as antioxidant effect. On the other hand, it is volatile and insoluble and is a skin irritant. In this case, nanostructured systems have been successfully employed as a drug carrier for skin diseases since they improve both biological and pharmaceutical properties of active compounds. The cytotoxic, antioxidant, and anti-inflammatory effects of EUG were assessed in human neutrophils and keratinocytes. Additionally, polymeric nanocarries (NCEUG) were prepared to improve the chemical and irritant characteristics of EUG. EUG presented apparent safety and antioxidant and anti-inflammatory effects on human neutrophils, but presented cytotoxic effects on keratinocytes. However, the nanocapsules were able to reduce its cytotoxicity. An in vivo experiment of irritant contact dermatitis (ICD) in mice induced by TPA showed that NCEUG reduced significantly the ear edema in mice when compared to the EUG solution, as well as the leukocyte infiltration and IL-6 level, possibly due to better skin permeation and irritancy blockage. These findings suggest that EUG is a promising bioactive molecule, and its nanoencapsulation seems to be an interesting approach for the treatment of ICD.
\end{abstract}

\section{Introduction}

Contact dermatitis accounts for $70-90 \%$ of all occupational skin diseases and describes the allergic skin reaction resulting from exposure to irritants (irritant contact dermatitis (ICD)) or to allergens (allergic contact dermatitis $(\mathrm{ACD}))[1]$.

Several alterations are observed in epidermal cells during ICD. In some cases, such changes are limited to the superficial layers of the epidermis. In the course of the inflammatory process, the production of IL- 8 by keratinocytes with consequent recruitment of polymorphonuclear neutrophils (PMNs) accumulates in the damaged epidermis, leading to the formation of intraepidermal pustules [2].

In ICD, an array of reactive oxygen species (ROS) is produced. ROS are set free by inflammatory mediators, generated directly by irritants [3-5], and released during free radical chain reactions. The main source of ROS is inflammatory cellular infiltrate. Stimulated cells produce superoxide; the respiratory burst of infiltrating PMNs in inflamed skin will produce high local levels of superoxide anion and hydrogen peroxide. Excessive production of 
ROS results in peroxidation of cell membrane lipids and damages of proteins and DNA $[6,7]$. The ROS such as superoxide can rapidly combine with nitric oxide (NO) to form reactive nitrogen species (RNS), such as peroxynitrite, and is three to four times faster than the dismutation of superoxide by superoxide dismutase (SOD). The RNS, in turn, induces nitrosative stress, which adds to the proinflammatory burden of ROS in keratinocytes [8].

Despite the enormous progress made in recent decades regarding the understanding of the pathophysiology of contact dermatitis, the ideal pharmacotherapy of both irritating as allergic contact dermatitis remains a research target [9]. Despite the existence of anti-inflammatory drugs such as corticosteroids, the topical therapies have disadvantages, such as the induction of cell atrophy, decreased skin barrier regeneration, and alteration of the dermal barrier. In this case, the search for new options for the treatment of ICD becomes necessary.

Eugenol (4-allyl-2-methoxyphenol (EUG)) is a terpene and presents itself as yellow viscous oil at normal temperature. Previous studies have reported biological activities of EUG including antibacterial [10], antifungal [11, 12], and antiallergic $[13,14]$ properties. The antiasthmatic effect of EUG has been recently reported in a mouse model where EUG was shown to influence the vitamin D3-upregulated protein $1 / \mathrm{NF}-\kappa \mathrm{B}$ pathway [15]. Also, the inhibition effect of EUG on key enzymes related to diabetes and hypertension [16] was reported in a study that involved both in vitro and in vivo model systems. Furthermore, it has been shown that EUG suppresses the activity of $\mathrm{Cl}^{-}$Channel TMEM16A [17]. Recently, EUG has attracted the attention of many researchers because of its anti-inflammatory and chemoprotective effects as well as its antioxidant activity [18] due to the phenolic group present in its structure. Because of wide pharmacological and biological activities, studies with the EUG and plant species that contain this substance are still a priority in research. With regard to the inflammatory process, several studies demonstrate the anti-inflammatory activity of EUG. It was shown that EUG promoted a reduction in carrageenan-induced pleural volumes in mice [19]. Furthermore, EUG causes inhibition of proinflammatory mediators such as COX-2, NF- $\kappa \mathrm{B}$, IL-6, leukotriene $\mathrm{C} 4$, and 5-LOX [20-22].

Nanoparticles are colloidal structures $(\sim 200 \mathrm{~nm})$ generally made of polymers or lipids which have been used as a drug delivery system since they have the ability to effectively deliver drugs to target sites. Specifically, nanocapsules are a reservoir system composed of an oily core surrounded by a polymer membrane and they are of interest for skin administration because of controlled release of encapsulated active ingredients, which need to diffuse through the polymeric matrix to permeate the skin. Their small size ensures a close interaction with the stratum corneum, and due to their occlusive properties (film formation on the skin), an increased skin hydration effect can be achieved [23, 24]. Also, the penetration of the active compound in the skin layers can be modulated depending on the nanoparticle surface charge; since the biological membranes are negatively charged, anionic nanocarriers have a low penetration profile as cationic ones can reach the deep dermis [25].

Despite the potential pharmacological properties of EUG, it is volatile and presents an irritant effect on the skin, resulting in allergic reactions which limit its use in topic formulations [26]. To overcome it and explore the pharmacological potential of EUG, the present research is aimed at investigating the cytotoxicity and anti-inflammatory profile of EUG both in vitro and in vivo, as well as to develop a nanoformulation for topical application. As strategy, polymeric nanocapsules constituted of Eudragit ${ }^{\circledR}$ S100 (an anionic copolymer composed of methacrylic acid and methyl methacrylate) were prepared to retain its penetration in the superficial layers of the skin, since the negative charge of the polymer reduces its interaction with skin cells and the drug penetration [27], which is desirable for dermatitis.

\section{Material and Methods}

2.1. Chemicals. Eugenol (EUG), dexamethasone, medium-chain triglycerides ( $\mathrm{Miglyol}^{\circledR}$ ), 12-O-tetradecanoylphorbol-13-acetate (TPA), dimethyl sulfoxide (DMSO), bromide, 3[4,5-dimethylthiazol-2-yl]-2,5-diphenyltetrazolium bromide (MTT), Triton $\mathrm{X}-100,3,3^{\prime}, 3,5^{\prime}$-tetramethylbenzidine (TMB), hexadecyltrimethylammonium bromide (HTAB) solution, polysorbate 80 , lucigenin ( $N, N^{\prime}$-dimethyl-9, $9^{\prime}$-biacridinium dinitrate), luminol (5-amino-2,3-dihydro-1,4-phthalazinedione), Trypan Blue, and quercetin were purchased from SigmaAldrich (St. Louis, MO, USA). Eudragit ${ }^{\circledR}$ S100 was obtained from Evonik (Essen, Germany). DMEM culture medium, gelatin (microbiological grade), and fetal bovine serum were purchased from Difco, Becton, Dickinson and Company in Sparks, Detroit, MN, USA.

2.2. Isolation of Human Neutrophils. Human leukocyte-rich blood from healthy adults was obtained from HEMOCE (blood bank), Fortaleza, Brazil. Neutrophils were isolated by Lucisano and Mantovani's method [28] with slight modifications [29]. In the present study, the cell suspension contained $80-90 \%$ neutrophils with viability of $90 \pm 2.0 \%$ established by the exclusion with Trypan Blue.

2.3. Human Keratinocytes. Human keratinocyte cells (HaCaT) were obtained from the Rio de Janeiro Cell Bank, Brazil. They were routinely grown in $150 \mathrm{~cm}^{2}$ tissue culture flasks in DMEM, supplemented with $1 \%(v / v)$ of an antibiotic solution containing $5 \mathrm{mg}$ of penicillin, $5 \mathrm{mg}$ of streptomycin, and $10 \mathrm{mg}$ of neomycin per $\mathrm{mL}$ and $7.5 \%$ or $10.0 \%(v / v)$ heatinactivated fetal bovine serum at $37^{\circ} \mathrm{C}$ under $5 \% \mathrm{CO}_{2}$.

2.4. Animals. The experiments were conducted using male albino mice (Mus musculus) of Swiss variety (25 to $30 \mathrm{~g}$ ), from the Animal House of the Federal University of Ceará. The animals were maintained at $22 \pm 2^{\circ} \mathrm{C}, 12 / 12 \mathrm{~h}$ light/dark cycle, and provided food and water ad libitum. Experiments were performed according to the Guide of Care and Use of Laboratory Animals from the European Community. All the experimental protocols were previously approved by our Institutional Ethics Committee (\#62/16). 


\subsection{Preclinical In Vitro Evaluation of EUG: Cytotoxicity and Anti-inflammatory and Antioxidant Properties}

2.5.1. MTT Test. In a preliminary study, human neutrophils $\left(2.5 \times 10^{6}\right.$ cells $\left./ \mathrm{mL}\right)$ were incubated for 30 minutes at $37^{\circ} \mathrm{C}$ in the presence of EUG $(5,10,25,50$, and $100 \mu \mathrm{g} / \mathrm{mL})$ or DMSO (1\%, vehicle control), Hank's balanced salt solution (HBSS: nontreated cells), and Triton X-100 (0.2\%—standard cytotoxic) in a 96-well plate. After this period, the plate was centrifuged at $2000 \mathrm{rpm}$ for 15 minutes at $25^{\circ} \mathrm{C}$ and the supernatant discarded as well as a new incubated solution $(200 \mu \mathrm{L})$ containing $10 \%$ of MTT at a concentration of $10 \mathrm{mg} / \mathrm{mL}$, and these cells were incubated again for another 3 hours. Finally, the plate was centrifuged again under the same conditions as above; the supernatant was discarded and then $150 \mu \mathrm{L}$ of pure DMSO added for cell lysis and solubilization of formazan. At this time, the plates were shaken for 15 minutes. The absorbance was measured by a microplate reader at $550 \mathrm{~nm}$. Cell viability was expressed by percentage [30]. In addition, taking into account that the skin is composed of specific cell types and EUG could be used as treatment for ICD, further MTT tests were conducted using human keratinocytes. For that, the cells were incubated with EUG (same doses), but at different times $(24,48$, or $72 \mathrm{~h})$ in order to observe the effect of both shortand long-term exposure.

2.5.2. Cell Membrane Integrity. Cell membrane integrity was assessed by flow cytometry according to the method described by [31]. Neutrophils $\left(2.5 \times 10^{6}\right.$ cells $\left./ \mathrm{mL}\right)$ were incubated with EUG $(10,25$, and $50 \mu \mathrm{g} / \mathrm{mL}$ ) or DMSO (vehicle control-1\%) for 30 minutes. Subsequently, cell pellets were suspended in $300 \mu \mathrm{L}$ of a hypotonic solution of PI $(2 \mu \mathrm{g} / \mathrm{mL})$ and sodium citrate $(0.1 \%)$. Under these conditions, the cells were incubated for 45 minutes at room temperature and in the dark. In this assay, cells with membrane disrupted the entry of propidium iodide and emitted high fluorescence. Fluorescence was measured in the FL2 site (orange-red fluorescence-585/42 nm) by flow cytometry (FACSCalibur, Benton Dickinson, CA, USA). Ten thousand events were acquired per sample.

2.5.3. Degranulation Assay. Following Boyum [32], neutrophils $\left(2.5 \times 10^{6}\right.$ cells $\left./ \mathrm{mL}\right)$ were suspended in buffered HBSS. The cells were incubated with EUG $(5,10,25,50$, and $100 \mu \mathrm{g} / \mathrm{mL})$, indomethacin $(100 \mu \mathrm{M}$, standard drug), DMSO (1\% $v / v$, vehicle), or HBSS (not treated cells group) for $15 \mathrm{~min}$ at $37^{\circ} \mathrm{C}$. Human neutrophils were stimulated by the addition of PMA $(0.1 \mu \mathrm{M})$ for $15 \mathrm{~min}$ at $37^{\circ} \mathrm{C}$. The reaction was stopped by cooling, and the suspension was centrifuged at $2000 \mathrm{~g}$ for $10 \mathrm{~min}$ at $4^{\circ} \mathrm{C}$. Aliquots $(50 \mu \mathrm{L})$ of the supernatants were added to phosphate-buffered saline [PBS $(100 \mu \mathrm{L})]$, phosphate buffer $(50 \mu \mathrm{L}, \mathrm{pH} 7.0)$, and $\mathrm{H}_{2} \mathrm{O}_{2}$ $(0.012 \%)$. After $5 \mathrm{~min}$ at $37^{\circ} \mathrm{C}, 3,3^{\prime}, 5,5^{\prime}$-tetramethylbenzidine $(1.5 \mathrm{mM}, 20 \mu \mathrm{L})$ was added, and the reaction was stopped with $30 \mu \mathrm{L}$ of sodium acetate (1.5 M, pH3.0). The results are expressed as percentage of inhibition of the release of MPO by stimulated human neutrophils.
2.5.4. ROS Production by Human Neutrophils. The chemiluminescent probes-luminol $(280 \mu \mathrm{M})$ or lucigenin $(150 \mu \mathrm{M})$ - and EUG $(1,10,50$ and $100 \mu \mathrm{g} / \mathrm{mL})$, DMSO ( $1 \%$, vehicle control), and quercetin $(25 \mu \mathrm{g} / \mathrm{mL}$, reference compound) were added to neutrophil suspensions $\left(2.5 \times 10^{6}\right.$ cells $\left./ \mathrm{mL}\right)$ and incubated for $30 \mathrm{~min}$ at $37^{\circ} \mathrm{C}$. The reaction was initiated by adding PMA $(0.1 \mu \mathrm{M})$. Chemiluminescence $(\mathrm{CL})$ responses were measured in a luminometer (Synergy HT, BioTek Instruments), where light emission was recorded in c.p.m. (counted photons per min) for $20 \mathrm{~min}$ at $37^{\circ} \mathrm{C}$. Background CL, produced by nonstimulated cells, was also determined. Results were expressed by the emission of chemiluminescence [33].

\subsection{Nanoformulation of EUG: Development and Preclinical In Vitro Evaluation}

2.6.1. Preparation and Physical Chemical Characterization. Nanocapsule suspensions were prepared by interfacial deposition of the preformed polymer, where an organic phase containing the polymer and oil is poured into an aqueous phase containing the surfactant [34]. Considering that EUG is a volatile oil and it was lost during the concentration procedure in a preliminary study, the formulation composition and preparation was adapted as described elsewhere [35]. So, the organic phase consisted of the anionic methacrylate polymer Eudragit ${ }^{\circledR}$ S100 $(0.5 \mathrm{~g})$ and EUG $(0.25 \mathrm{~g})$ dissolved in acetone $(15 \mathrm{~mL})$ and the aqueous phase $(23 \mathrm{~mL})$ contained polysorbate 80 as surfactant $(0.192 \mathrm{~g})$. Blank formulations (NCB) were prepared omitting EUG in the organic phase and replacing it for medium-chain triglycerides (Miglyol ${ }^{\circledR}$, $160 \mu \mathrm{L}$ ). All formulations were prepared in triplicate. Particle sizes and polydispersity indices $(n=3)$ were measured by photon correlation spectroscopy (Zetasizer Nano ZS, Malvern, UK). The samples were diluted $1: 100(v / v)$ in ultrapure water, and the measurements were performed in triplicate. The zeta potential values were determined by electrophoretic mobility using the same instrument at $25^{\circ} \mathrm{C}$ and after the sample dilution $(1: 100, v / v)$ in $10 \mathrm{mM} \mathrm{NaCl}$. The $\mathrm{pH}$ values of the formulations were determined using a calibrated potentiometer (Hanna, Rhode Island, USA), at room temperature. The EUG content in the nanocapsule suspension was performed using a chromatographic system (Waters, USA) coupled with a diode array detector (HPLC-PDA), autosampler, and column oven. The separation was carried out using a C18 column (Phenomenex, $250 \times 4.6 \mathrm{~mm}, 5 \mu \mathrm{m}$ ) coupled to a precolumn (Phenomenex) with similar constitution at $40^{\circ} \mathrm{C}$. The mobile phase consisted of water:methanol (85: $15, v / v)$, and it was eluted in isocratic mode $(0.8 \mathrm{~mL} / \mathrm{min})$. The detection was set at $280 \mathrm{~nm}$ [36]. Encapsulation efficiency was performed by ultrafiltration-centrifugation as described elsewhere [37]. Additionally, a preliminary stability study was carried out. Formulations were packaged in amber glass containers and stored at room temperature $\left(25 \pm 2^{\circ} \mathrm{C}\right)$ and protected from light. They were monitored during 2 months by means of size, polydispersity, zeta potential, and $\mathrm{pH}$. Also, the EUG content was determined after 30 and 60 days of storage.

2.6.2. Cytotoxicity Evaluation. In order to evaluate the safety of the nanocarriers (containing or not EUG) for the 
treatment of ICD, the MTT test was performed using human keratinocytes as previously described. The cells were incubated with NCEUG $(5,10,25,50$, and $100 \mu \mathrm{g} / \mathrm{mL})$ or NCB (volume correspondent to the higher volume of NCEUG), Hank's balanced salt solution (HBSS: nontreated cells), or Triton X-100 (0.2\%-standard cytotoxic) in a 96-well plate for 24,48 , and $72 \mathrm{~h}$.

\subsection{Preclinical In Vivo Evaluation of EUG and NCEUG}

2.7.1. TPA-Induced Acute Ear Edema. Mice in groups $(n=8)$ were treated on their right ear with EUG or NCEUG (0.125; 0.25 and $0.5 \mathrm{mg} /$ ear, $10 \mu \mathrm{L})$, vehicle ( $1 \%$ acetone or NCB), or dexamethasone $(0.05 \mathrm{mg} / \mathrm{ear})$ prior to topical application of TPA. Ear thickness was recorded before and four hours after administration of TPA making use of a digital caliper $\left(100.174 \mathrm{~B} /\right.$ Digimess $\left.^{\circledR}\right)$ [38]. Ear punch biopsies $(5 \mathrm{~mm})$ were collected for the determination of myeloperoxidase [39].

2.7.2. Mouse Ear Edema Induced by Multiple Topical Applications of TPA. Chronic inflammation was induced by topical application of $20 \mu \mathrm{L}$ of TPA $(2.5 \mu \mathrm{g} /$ ear $)$ to the left ear of mice of each mouse with a micropipette on alternate days. The test compounds were dissolved in acetone and applied topically as the same concentrations of acute edema assay twice daily for four days, in the morning immediately after TPA application and $6 \mathrm{~h}$ later [38]. Dexamethasone was used as the reference drug $(0.5 \mathrm{mg} /$ ear). Ear thickness was recorded before and seven hours after administration of TPA making use of a digital caliper (100.174B/Digimess $\left.{ }^{\circledR}\right)$.

2.7.3. Measurement of IL-6 and Neutrophil KC (CXCL 1) Levels. Swiss mice had the left ear sample removed on day 4 for the analysis of cytokines. The samples were stored at $-70^{\circ} \mathrm{C}$ until required for the assay. The collected tissue was homogenized and processed [40]. The concentrations of $I L-$ 6 and neutrophil KC were determined using an enzymelinked immunosorbent assay (ELISA) [41]. Briefly, microtiter plates were coated with an antibody against mouse $I L-6$ and neutrophil KC $(4 \mu \mathrm{g} / \mathrm{mL}$, DuoSet ELISA Development kit, $R \& D$ Systems) overnight at $4^{\circ} \mathrm{C}$. After blocking the plates, the sample and standard were added at various dilutions in duplicate and incubated at $4^{\circ} \mathrm{C}$ for $2 \mathrm{~h}$. The plates were washed three times with buffer. After washing the plates, biotinylated goat anti-mouse (diluted 1:1000 with assay buffer 1\% BSA, R\&D Systems, USA) was added to the wells. After a further incubation at room temperature for $2 \mathrm{~h}$, the plates were washed, and $100 \mu \mathrm{L}$ of streptavidin-HRP diluted $1: 200$ was added. To the plate, $100 \mu \mathrm{L}$ of substrate solution ( $1: 1$ mixture of $\mathrm{H}_{2} \mathrm{O}_{2}$ and tetramethylbenzidine; R\&D Systems, USA) was added, and the plate was incubated in the dark at room temperature for $20 \mathrm{~min}$. The enzyme reaction was stopped with $\mathrm{H}_{2} \mathrm{SO}_{4} 2 \mathrm{~N}$, and the absorbance was measured at $450 \mathrm{~nm}$. The results are expressed as $\mathrm{pg} / \mathrm{g}$ of tissue and reported as mean \pm SEM.

2.8. Statistical Analysis. Statistical analyses were performed using GraphPad Prism 5.0 (USA), and the results are expressed as mean $\pm \mathrm{SD}$ (formulations) or mean $\pm \mathrm{SEM}$ (in vitro and in vivo tests). The comparison of means was

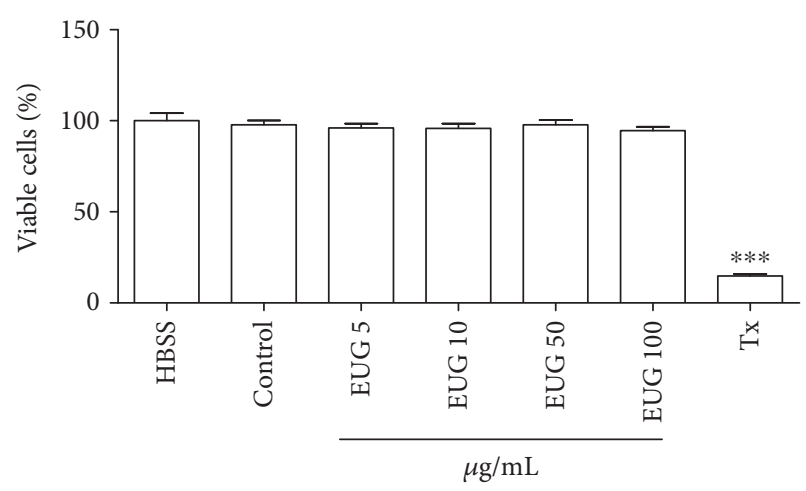

FIgUre 1: Evaluation of EUG toxicity on MTT test in human neutrophils. Data from three to eight samples. The control group consists of cells treated with vehicle (DMSO 1\%). Triton X-100 (Tx, $0.02 \%)$ was used as cytotoxic standard. *vs. HBSS: nontreated cells. $p<0.05$ (ANOVA and Tukey as the post hoc test).

performed using analysis of variance (ANOVA) followed by Tukey's test. Differences were considered statistically significant when $p<0.05$.

\section{Results and Discussion}

3.1. EUG Is Not Cytotoxic and Did Not Alter Cell Membrane Stability. In order to verify the possible cytotoxicity of EUG, we investigated its effects on cellular metabolism with the MTT test and cell membrane integrity in human neutrophils. As presented in Figure 1, the addition of EUG $(5-100 \mu \mathrm{g}$ / $\mathrm{mL})$ to neutrophils did not cause a significant reduction on cell viability $(96.03 \pm 2.52,95.87 \pm 2.63,97.76 \pm 2.64$, and $94.59 \pm 2.13 \%$, respectively) measured by the MTT test after 30 minutes of incubation when compared to the control group (DMSO 1\%: $97.86 \pm 2.34 \%$ ). In this assay, it was observed that EUG unlike Triton X-100 (standard, cytotoxic) did not interfere cell viability in relation to the groups control (vehicle) and RPMI (nontreated cells), suggesting the absence of toxicity on cellular metabolism, particularly related to the activity of the mitochondrial succinate dehydrogenase enzyme.

Some assays may be used to investigate the possible effect of drugs on the pattern of cell death including the detection of cell morphological changes by light microscopy, electron microscopy, or flow cytometry [42]. Following the safety evaluation studies of EUG, the flow cytometry methodology was used, since the technique is a tool that provides in a quick way the objective of the determination of biological parameters such as cell size, cell type, DNA content, and enzymatic function. In the determination of membrane integrity, the dye propidium iodide (PI) was used, which has the capacity to bind to the DNA of the cell, allowing the identification of cellular viability and fragmentation of the nuclear material. PI penetrates only cells that have membrane changes, emitting high red fluorescence when excited at $488 \mathrm{~nm}$ [31]. Thus, the greater the fluorescence emitted by the cell, the greater the change in permeability of the plasma membrane that can culminate in cell death. The membrane integrity assessment in human neutrophils revealed that the 


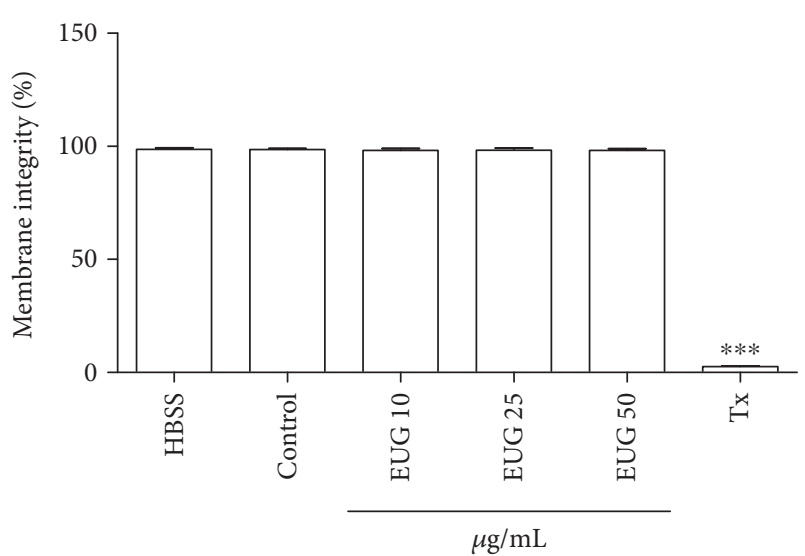

FIGURE 2: Effect of EUG on the percentage of measurement of membrane integrity of human neutrophils as monitored by flow cytometry using the sensitive fluorochrome propidium iodide. Neutrophils were cultured for $30 \mathrm{~min}$ in the presence of EUG at various concentrations $(10-50 \mu \mathrm{g} / \mathrm{mL})$. Values are presented as means \pm SEM of 3 separated experiments in triplicate and by analysis of 10,000 events. The control group consists of cells treated with vehicle (DMSO 1\%). *vs. HBSS: nontreated cells. $p<0.001$ (ANOVA and Tukey as the post hoc test).

incubation with EUG $(10,25$, and $50 \mu \mathrm{g} / \mathrm{mL})$ within 30 minutes did not cause membrane disruption $(98.21 \pm 0.85$, $98.28 \pm 0.88$, and $98.15 \pm 0.77 \%$, respectively) compared to the control group $(98.50 \pm 0.60)$ (Figure 2). Studies with flow cytometry showed that treatment with EUG did not promote a significant decrease in the number of cells when compared to the control group. A study by Thompson et al. [43] to investigate the effect of EUG on human neutrophils showed that incubation of the drug at the maximum concentration of $1 \mathrm{mM}$ did not promote significant cytotoxicity. Both results suggest absence of toxicity on the human neutrophil.

3.2. EUG Prevents Human Neutrophil Degranulation. The effect of EUG on neutrophil degranulation was investigated by measurement of myeloperoxidase release after the exposure of the cells to PMA (Figure 3). EUG $(1-100 \mu \mathrm{g} / \mathrm{mL}$ ) and indomethacin $(36 \mu \mathrm{g} / \mathrm{mL})$, a nonselective inhibitor of cyclooxygenase, inhibited the degranulation process of human neutrophil induced by PMA. EUG inhibited the PMA-stimulated neutrophil degranulation by $84 \%$.

In the present study, we show that EUG inhibits proinflammatory mechanisms of human neutrophils, an effect that can contribute for the control of several inflammatory diseases such as dermatitis [44]. The treatment of human neutrophils with EUG significantly decreases the MPO amount released by the cells induced by PMA which is a receptor-independent stimulant which enters the cell and directly activates protein kinase $\mathrm{C}$ leading to the assembly and activation of NADPH oxidase [45]. MPO is a key constituent of the neutrophil granules that catalyzes the formation of hypochlorous acid, a compound with potent oxidant and microbicidal effects [46]. MPO not only serves as an index

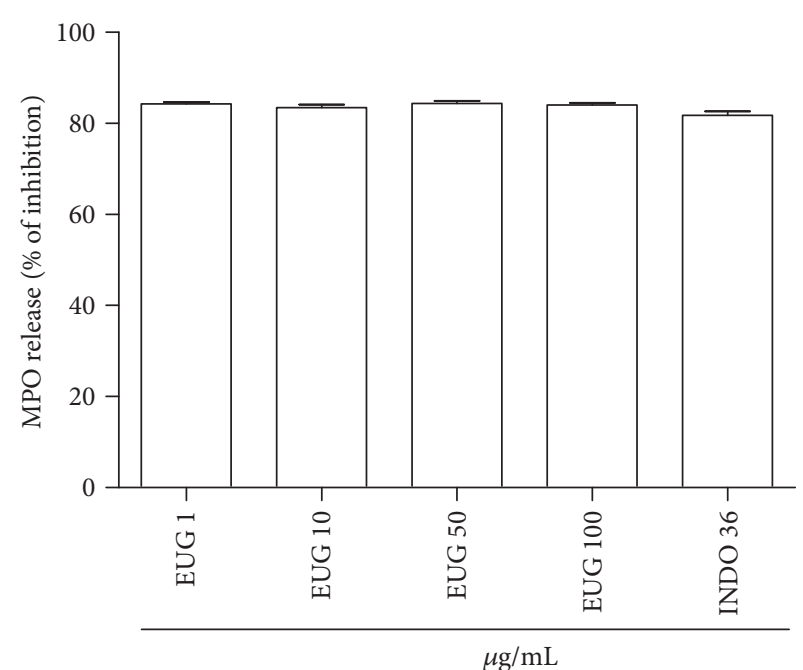

FIgURE 3: Effects of eugenol (EUG) on the release of human neutrophil myeloperoxidase (MPO) stimulated by phorbol myristate acetate (PMA). Freshly isolated cells $\left(2.5 \times 10^{6}\right)$ were preincubated with indicated concentrations of EUG prior to the addition of PMA $(0.1 \mu \mathrm{g} / \mathrm{mL})$. Indomethacin $(36 \mu \mathrm{g} / \mathrm{mL})$ was used as positive control. Data are expressed as percentages of inhibition by EUG on the release of MPO. Numbers represent mean \pm SEM. Data from three to eight samples.

of neutrophil recruitment and activation but also displays cytokine-like properties that can serve to modulate the activation state of leukocytes in the inflammatory process [47]. In the present study, EUG strongly inhibited MPO release.

3.3. Treatment with EUG Inhibits Neutrophil ROS Generation. The inhibitory effect of EUG on the superoxide anion and total ROS generation by PMA-stimulated human neutrophil was assessed by the lucigenin- (LucCL-) and luminol- (LumCL-) enhanced chemiluminescence assays, respectively (Figure 4). EUG at $100 \mu \mathrm{g} / \mathrm{mL}$ inhibited significantly $(p<0.05)$ the PMA-stimulated human neutrophils LumCL $(77.16 \pm 0.34 \%)$ and LucCL (51.40 $\pm 2.1 \%)$ (Figures 4(a) and 4(b), respectively). The reference compound quercetin at $25 \mu \mathrm{g} / \mathrm{mL}$ inhibited LucCL and LumCL by $56.80 \%$ and $72.09 \%$, respectively.

Oxidative stress is defined as an accumulation of reactive oxygen and nitrogen species that damage the structure of biomolecules such as DNA, lipids, carbohydrates, and proteins, as well as other cellular components, and can initiate inflammatory responses through the activation of redoxsensitive systems [48]. Furthermore, lipid degradation of the membrane (lipid peroxidation) induced by ROS can produce proinflammatory bioactive molecules that affect monocyte and neutrophil functions, which have an important role in several chronic inflammatory diseases $[8,49]$ such as dermatitis [50-52]. Thus, we investigated whether EUG had a modulatory effect in ROS production induced by PMA in human neutrophils measured by the luminol or lucigenin-enhanced chemiluminescence $(\mathrm{CL})$ technique. It was observed that EUG reduced the ROS production in both luminol- or lucigenin-dependent chemiluminescence assays. The luminol probe can detect several intra- and extracellular 


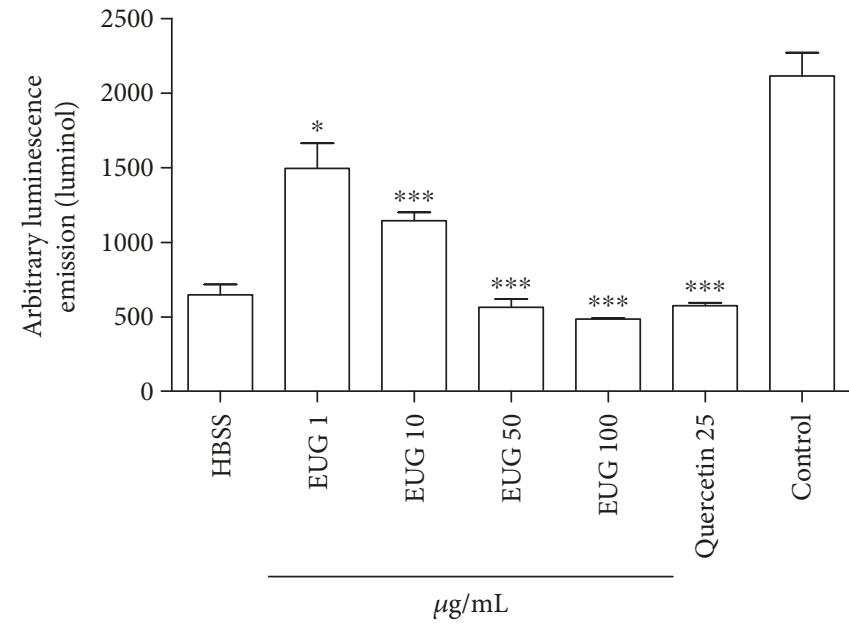

(a)

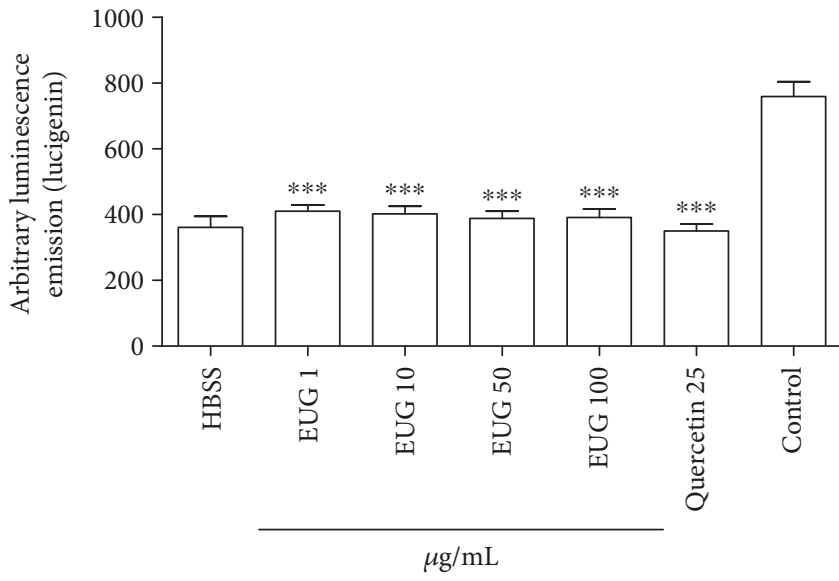

(b)

FIGURE 4: Evaluation of antioxidant activity of EUG in human neutrophils by chemiluminescence (CL). The inhibitory effect of EUG in human neutrophil oxidative metabolism was assessed by luminol (LumCL) (a) or lucigenin (LucCL) (b). Data from three to eight samples. *vs. control (DMSO), $p<0.05$, and ${ }^{* * *}$ vs. control (DMSO), $p<0.001$ (ANOVA and Tukey as the post hoc test).

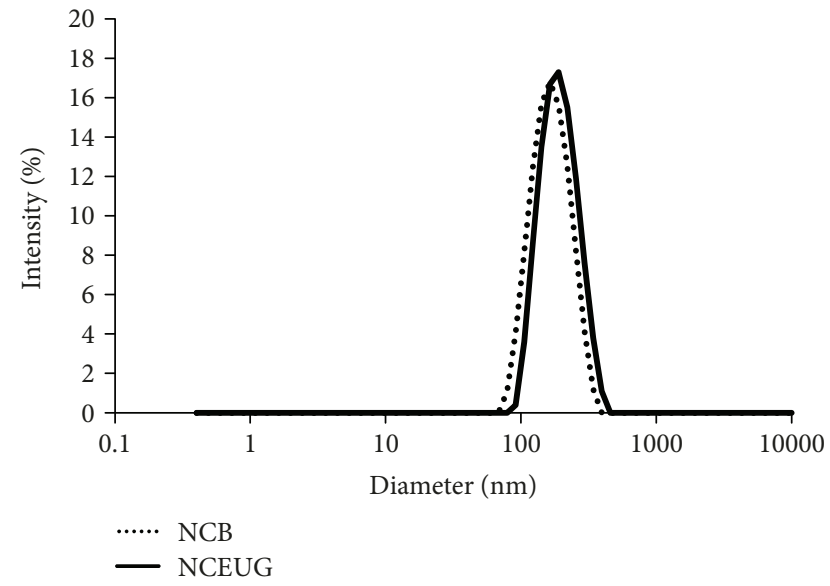

Figure 5: Size distribution by photon correlation spectroscopy of the eugenol-loaded nanocapsules (NCEUG) and the blank formulation (NCB).

reactive species, having higher sensitivity for the MPO$\mathrm{H}_{2} \mathrm{O}_{2}-\mathrm{HOCl}$ system, while the lucigenin probe detects mainly production by neutrophils. The effect of EUG is relevant because excessive generation of oxidants by the superoxide anion and $\mathrm{MPO}-\mathrm{H}_{2} \mathrm{O}_{2}-\mathrm{HOCl}$ system has been linked to tissue damage in many chronic inflammatory diseases, such as dermatitis [6]. The results obtained with EUG in this work corroborate previous studies demonstrating its antioxidant activity in PMA-stimulated neutrophils $[43,53]$ in which high concentrations of EUG $(164.20 \mu \mathrm{g} / \mathrm{mL})$ have inhibitory activity of superoxide anion formation.

3.4. Physicochemical Characterization and Stability of Eugenol-Loaded Polymeric Nanocapsules. The formulations presented unimodal size distribution (NCB: $146.1 \pm 2.1 \mathrm{~nm}$ and NCEUG: $154.5 \pm 1.4 \mathrm{~nm}$ ) as shown in Figure 5. The polydispersity index indicated narrow distribution $(\mathrm{PDI}<0.25)$.
TABLE 1: Stability of the eugenol-loaded nanocapsules stored at room temperature for 2 months.

\begin{tabular}{lccccc}
\hline Day & $\begin{array}{c}\text { Diameter } \\
(\mathrm{nm})\end{array}$ & PDI & $\begin{array}{c}\text { Zeta } \\
\text { potential } \\
(\mathrm{mV})\end{array}$ & $\mathrm{pH}$ & $\begin{array}{c}\text { Drug } \\
\text { content } \\
(\%)\end{array}$ \\
\hline 1 & $154 \pm 1$ & $0.03 \pm 0.01$ & $-20.9 \pm 0.4$ & $4.1 \pm 0.3$ & $83.4 \pm 0.5$ \\
30 & $159 \pm 1$ & $0.04 \pm 0.01$ & $-23.8 \pm 0.4$ & $4.2 \pm 0.1$ & $83.3 \pm 0.4$ \\
60 & $158 \pm 4$ & $0.04 \pm 0.02$ & $-18.8 \pm 0.1$ & $4.3 \pm 0.1$ & $83.3 \pm 0.3$ \\
\hline \multicolumn{7}{l}{ The values represent mean $\pm \mathrm{SD}(n=3)}$.
\end{tabular}

Zeta potential values, which reflect the surface charge of the nanoparticles, were $-21.6 \pm 1.3 \mathrm{mV}$ and $-13.2 \pm 2.0 \mathrm{mV}$ for NCEUG and NCB, respectively. The $\mathrm{pH}$ of the formulations were 3.4 (NCEUG) to 4.3 (NCB). The EUG content was $8.4 \pm 0.5 \mathrm{mg} / \mathrm{mL}$ and the encapsulation efficiency $90 \%$. Along 2 months of storage, no macroscopic changes such as creaming, sedimentation, or flocculation were observed. In addition, no changes in the size, PDI, zeta potential, $\mathrm{pH}$, and EUG content were also verified (Table 1).

3.5. EUG Reduces Human Keratinocyte Viability, but Nanoencapsulation Reduces Its Cytotoxicity. As shown in Figure 6(a), it can be seen that the addition of EUG to human keratinocytes $(\mathrm{HaCaT})$ caused a significant reduction in cell viability measured by the MTT test at concentrations of 50 and $100 \mu \mathrm{g} / \mathrm{mL}(11.93 \pm 1.18$ and $26.69 \pm 0.70$, respectively) after $24 \mathrm{~h}$ of incubation when compared to the control group (DMSO 1\%: 82.98 $\pm 1.53 \%$ ). On incubation of 48 (Figure 6(b)) and $72 \mathrm{~h}$ (Figure 6(c)), EUG promoted reduction in cell viability at concentrations of 50 and $100 \mu \mathrm{g} / \mathrm{mL}$ $(26.50 \pm 2.19$ and $19.70 \pm 1.11 \%)$ when compared to the control group (DMSO 1\%-48h: $101.5 \pm 5.93 \%$; $72 \mathrm{~h}$ : $91.51 \pm 2.28 \%$ ). Some studies of EUG and isoeugenol cytotoxicity demonstrated that these molecules promote growth suppression in keratinocytes ( $\mathrm{HaCaT})$ and that the effects may be mediated through interactions with the aryl 
$24 \mathrm{~h}$

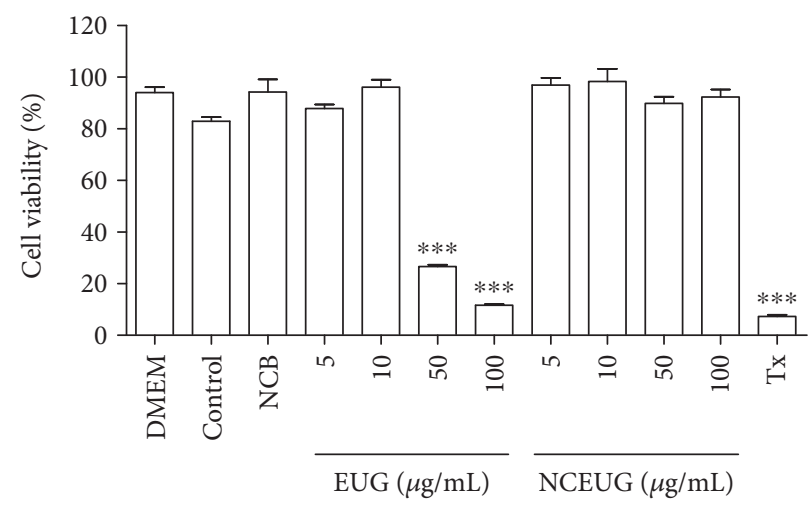

(a)
$48 \mathrm{~h}$

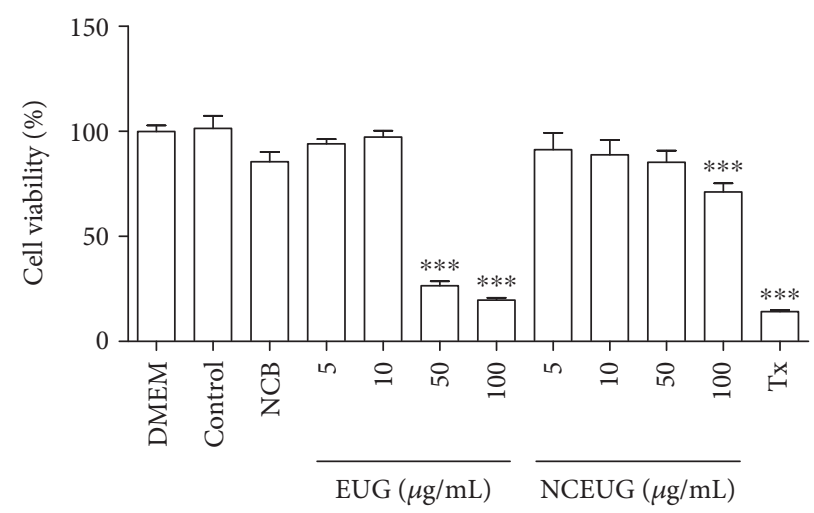

(b)

$72 \mathrm{~h}$

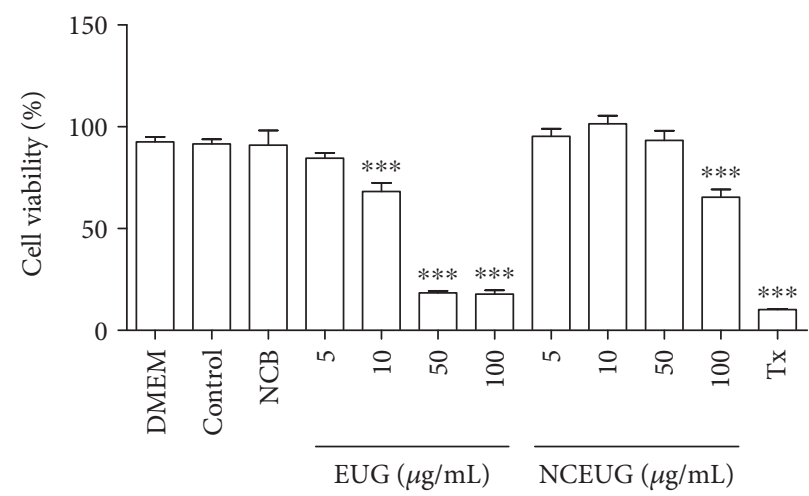

(c)

Figure 6: Evaluation of EUG and NCEUG toxicity on MTT test for 24 hours, 48 hours, and 72 hours in human neutrophils. Data from two to eight samples. The control group consists of cells treated with vehicle (DMSO 1\%). *vs. DMEM: untreated cells. $p<0.05$ (ANOVA and Tukey as the post hoc test).

hydrocarbon receptor (AHR) [54]. In a later study, Kalmes and Blömeke [55] demonstrated that the effects of EUG and isoeugenol were determined on AHR intracellular localization, expression of the target gene AHR, regulation of cell cycle-dependent AHR, and proliferation of $\mathrm{HaCaT}$ cells. Both compounds produced a rapid and marked translocation to the nucleus AHR, inducing the expression of target genes AHR as cytochrome P450 1A1 (CYP1A1) and repressor (AHR AhRR), and inhibited proliferation of the HaCaT cells, showing that antiproliferative properties of EUG and isoeugenol are mediated through AHR in HaCaT cells. Despite these results, EUG still possesses notorious antioxidant and anti-inflammatory effects, so that we used nanocarriers as a strategy to overcome both its cytotoxicity on keratinocytes and its volatility, which is a problem regarding the topical application. When incubated with NCEUG $(5,10,50$, and $100 \mu \mathrm{g} / \mathrm{mL})$, the viability of the keratinocytes was not reduced $(87.52 \pm 3.14,96.94 \pm 2.75$, $98.33 \pm 429 ; 89.84 \pm 2.63$, and $92.32 \pm 2.93 \%$, respectively) compared to the blank formulation (NCB, 94.20 $\pm 4.95 \%$ ) (Figure 6(a)). However, the incubation of keratinocytes with NCEUG changed the viability of the cells only at a concentration of $100 \mu \mathrm{g} / \mathrm{mL}$ ( $48 \mathrm{~h}: 71.14 \pm 4.20 ; 72 \mathrm{~h}: 65.38 \pm 3.84 \%$ ) when compared to NCB ( $48 \mathrm{~h}: 85.53 \pm 4.72 \%$; $72 \mathrm{~h}: 90.89 \pm$
7.27\%) (Figures 6(b) and 6(c)). The improvement of the biological responses after nanoencapsulation has been reported [56], and the successfulness of NP-based delivery has been associated with their nanorange size and excellent biopharmaceutical properties, such as high entrapment efficiency, controlled release rates, and insignificant enzymatic degradation. So, NCEUG seemed to be a promising formulation for the treatment of ICD and it was submitted to in vivo experiments.

3.6. Nanoencapsulation Improves the In Vivo Antiinflammatory Properties of EUG. Considering the possibility that the absence of efficacy of EUG could be related to its irritant effect on skin [57], a nanosystem using EUG as active principle was developed. Figure 7 presents the antiedematogenic effect of the topical administration of EUG and NCEUG $(0.04,0.08$, and $016 \mathrm{mg} /$ ear $)$ on TPA-induced ear edema in mice. Pretreatment of animals with EUG at doses of $0.04,0.08$, and $0.16 \mathrm{mg} /$ ear did not promote reduction in ear edema thickness $(0.29 \pm 0.01,0.29 \pm 0.02$, and 0.33 \pm 0.01 , respectively), when compared to the control group $(0.32 \pm 0.03)$, corresponding to inhibitions of $5.20 \%, 7.81 \%$, and $7.50 \%$. Dexamethasone $(0.05 \mathrm{mg} / \mathrm{ear})$, used as the standard drug, significantly inhibited the thickness ( $\mathrm{mm}$ ) of ear 


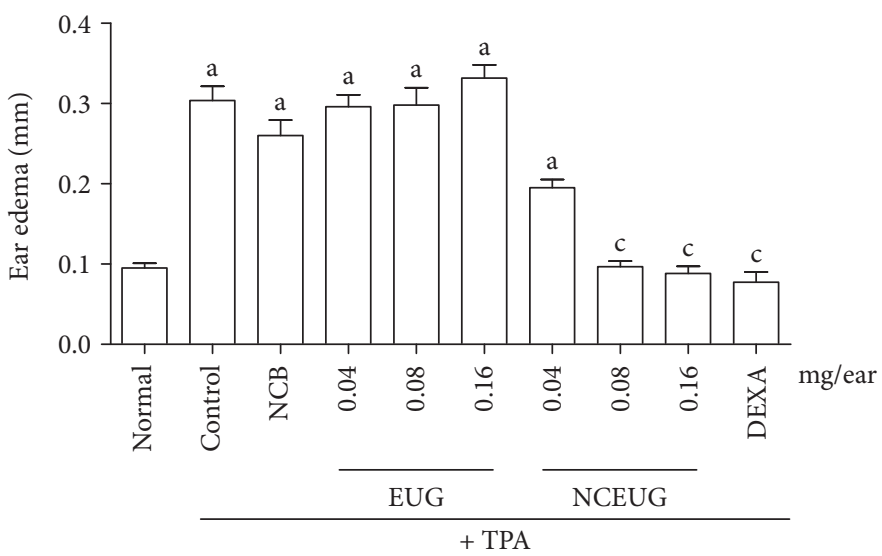

Figure 7: Effects from EUG and NCEUG on TPA-induced acute edema in mice. Swiss mice ( 25 to $30 \mathrm{~g})$ were treated topically with EUG or NCEUG $(0.04,0.08$, and $0.16 \mathrm{mg} / \mathrm{ear}$ ), NCB (blank formulations), dexamethasone (DEXA; $0.05 \mathrm{mg} / \mathrm{ear}$ ), or acetone (vehicle control) with topical application of TPA $(2.5 \mu \mathrm{g} /$ ear $)$ on the surface of the left ear of mice. Values represent mean \pm SEM from 8 animals per group. a vs. the normal group; b vs. control; c vs. NCB group; $p<0.05$ (ANOVA and Tukey's test).

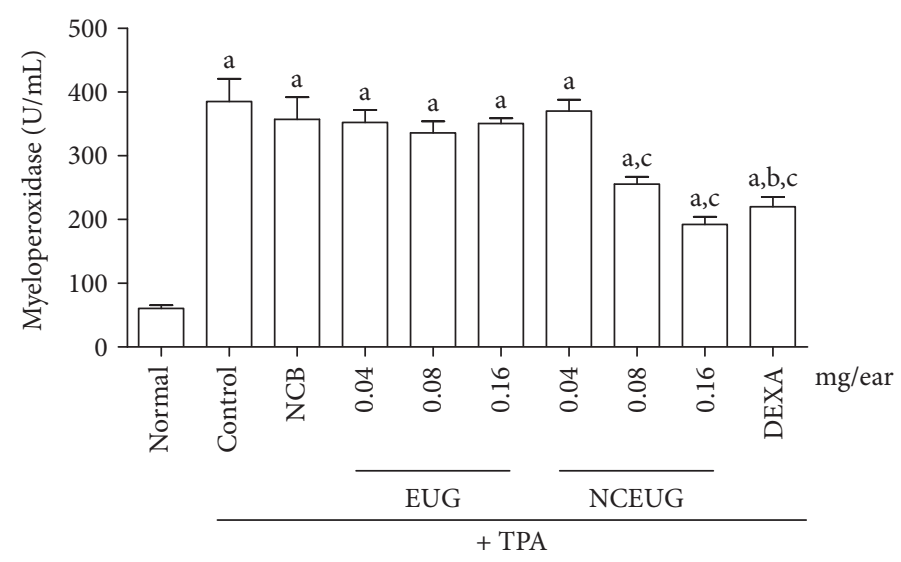

FIGURE 8: Effect of EUG on myeloperoxidase activity induced by TPA in mice. Swiss mice ( 25 to $30 \mathrm{~g}$ ) were treated topically with EUG or NCEUG $(0.04,0.08$, and $0.16 \mathrm{mg} /$ ear), dexamethasone (DEXA; $0.05 \mathrm{mg} /$ ear), or acetone (vehicle control) with topical application of TPA $(2.5 \mu \mathrm{g} / \mathrm{ear})$ on the surface of the left ear of mice. Values represent mean \pm SEM the amount of MPO in U/mL. 8 animals were used per group. a vs the normal group; b vs control group; c vs NCB; $p<0.05$ (ANOVA and Tukey's test).

edema with inhibition of $85.59 \%$. However, incorporation of EUG in nanocapsule suspensions (NCEUG; 0.08 and $0.16 \mathrm{mg} /$ ear) significantly reduced TPA-induced ear edema $(\mathrm{mm})$ in mice $(0.10 \pm 0.009,0.08 \pm 0.008)$, with inhibitions of $30.29,61.61$, and $68.82 \%$, when compared to the control group (NCB: $0.22 \pm 0.022$ ). These results corroborated with previous studies which showed that nanocarriers (nanoemulsion, nanocapsules, and nanospheres) are alternatives to topical administration showing a controlled drug release and improving the efficacy in the treatment of contact dermatitis. It was demonstrated that polymeric nanocapsules did not produce contact sensitization in mice stimulated by oxazolone [58]. Also, it was reported that nanocapsules containing clobetasol propionate, a corticosteroid used for treatment of skin disorders, in a model of contact dermatitis after topical administration in rats led to a better control of the drug release and provided better in vivo dermatological efficacy [59]. So, possibly this anti-inflammatory activity instead of an irritant effect on the skin observed in this study is related to the drug controlling on skin permeation.

The topical administration of EUG and NCEUG on the measurement of myeloperoxidase (MPO) in tissue of mice submitted to ear contact dermatitis induction with TPA (Figure 8) indicates that the treatment of animals with EUG at concentrations of $0.04,0.08$, and $0.16 \mathrm{mg} /$ ear were not able to reduce leukocyte infiltration expressed through the MPO levels $(352.10 \pm 19.84$ and $336.0 \pm 17.97350$ $\pm 8.57 \mathrm{U} / \mathrm{mL}$ ) corresponding to inhibitions of $18.75,15.93$, and $10.40 \%$, respectively, compared to the control group $(386.20 \pm 13.52 \mathrm{U} / \mathrm{mL})$. Dexamethasone $(0.05 \mathrm{mg} / \mathrm{ear})$, an anti-inflammatory drug standard, promoted reduction of MPO by $129.50 \pm 5.54 \mathrm{U} / \mathrm{mL}$ (66.40\% inhibition). NCEUG at concentrations of 0.08 and $0.16 \mathrm{mg} /$ ear reduced significantly $(p<0.05)$ the amount of MPO $(255.70 \pm 11.76 \mathrm{U} / \mathrm{mL}$ 


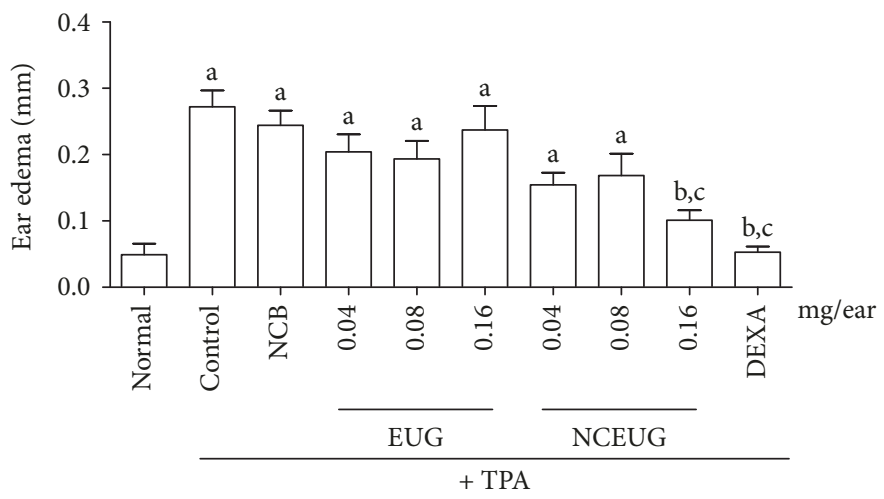

FIGURE 9: Antiedematogenic activity from EUG and NCEUG induced by TPA in mice. Swiss mice ( 25 to 30 g) were treated topically with EUG or NCEUG $(0.04,0.08$, and $0.16 \mathrm{mg} / \mathrm{ear}$ ), NCB (blank formulations), dexamethasone (DEXA; $0.05 \mathrm{mg} / \mathrm{ear}$ ), or acetone (vehicle control) with topical application of TPA $(2.5 \mu \mathrm{g} /$ ear $)$ on the surface of the left ear of mice. Values represent mean \pm SEM from 8 animals per group. a vs the normal group; b vs control; c vs NCB group; $p<0.05$ (ANOVA and Tukey's test).

and $192.10 \pm 12.33 \mathrm{U} / \mathrm{mL}$ ), with inhibitions of 32.01 and $50.33 \%$, respectively, compared to the control group (NCB: $320.70 \pm 29.96 \mathrm{U} / \mathrm{mL}$, inhibition of $16.14 \%$ ).

Figure 9 demonstrates the effect of multiple topical administrations of EUG and NCEUG (0.04, 0.08 and $0.16 \mathrm{mg} / \mathrm{ear}$ ) in the ear edema induced by TPA in mice. Pretreatment of animals with EUG in all doses did not interfere significantly in the thickness $(\mathrm{mm})$ of ear edema $(0.20 \pm 0.02$, $0.24 \pm 0.03$, and $0.19 \pm 0.02$, respectively) when compared to the control group $(0.22 \pm 0.02)$, corresponding to inhibitions of $10 \%, 9 \%$, and $13 \%$. Dexamethasone $(0.05 \mathrm{mg} /$ ear, standard drug) inhibited significantly the ear thickness $(\mathrm{mm})$ with an inhibition value of $77 \%(0.05 \pm 0.008)$. Similar to acute ear edema, the incorporation of the nanocapsule suspension of EUG (NCEUG; $0.16 \mathrm{mg} / \mathrm{ear}$ ) significantly reduced the ear edema $(\mathrm{mm})$ induced by TPA in mice $(0.10 \pm 0.01)$ with inhibition of $54 \%$ when compared to the control group (NCB: $0.24 \pm 0.02 ; 9 \%$ of inhibition) promoting effects similar to dexamethasone, an anti-inflammatory standard drug.

Repeated application of TPA to sensitized mice caused an increase in tissue levels of IL- 6 and KC levels. The treatment with NCEUG $(0.16 \mathrm{mg} /$ ear $)$ significantly suppressed the TPA-induced IL-6 and neutrophil KC levels, yielding an average inhibition of $77 \%$ for both mediators (Figure 10).

It was observed in the results that the treatment of the animals with NCEUG (0.08 and $0.16 \mathrm{mg} /$ ear $)$ caused a significant reduction in the ear swelling ( $\mathrm{mm}$ ) on TPAinduced mice when compared to the EUG group. These results corroborated with previous studies which showed that nanocarriers (nanoemulsion, nanocapsules, and nanospheres) are alternatives to topical administration showing a controlled drug release and improving the efficacy in the treatment of contact dermatitis. It was demonstrated that polymeric nanocapsules did not produce contact sensitization in mice stimulated by oxazolone [58]. Also, it was reported that in a model of contact dermatitis after topical administration in rat nanocapsules containing clobetasol propionate, a corticosteroid used for treatment of skin disorders, it led to a better control of the drug release and provided better in vivo dermatological efficacy [59]. So, it is possible that the nanoencapsulation of EUG controlling the drug permeation on the skin allowed terpene to show an anti-inflammatory activity instead of the irritant effect on the skin.

There are few studies evaluating the effects of EUG in the ear edema model in mice (commonly employed for research of inflammatory skin diseases such as dermatitis). Among them, one showed that EUG at concentrations of 0.2 and $0.5 \mathrm{mg} /$ ear promotes significant reduction of edema induced by croton oil [60]. In disagreement, in the present study, EUG $(0.04,0.08$, and $0.16 \mathrm{mg} /$ ear $)$ did not show antiinflammatory effects in both models of mouse edema ear (acute and multiple). This result may be related at least in part with the lower dose of EUG and the type of skin irritant; although croton oil contains 12-o-tetradecanoylphorbol-13acetate (TPA) and other phorbol esters as main irritant agents, our study used the pure skin agent where, in skin and keratinocytes, TPA had a biphasic influence, stimulating immature basal cells to proliferate while accelerating differentiation in committed cells [60].

In addition, the acute assay of irritant contact dermatitis induced by TPA in mice using EUG showed that this terpene has no antiedematogenic action, but its incorporation into the polymeric nanocapsules reduced significantly the ear thickness after induction of edema with TPA similar to dexamethasone (standard drug). At least part of the anti-inflammatory activity of NCEUG is related to its ability to reduce the levels of MPO, IL-6, and KC (CXCL 1), markers of cell accumulation into the inflammatory focus. Polymeric nanoparticles (NP) have been applied to immunomodulatory therapies to enhance their efficacy and reduce potential side effects on the stratum corneum [61, 62] and are well recognized as an advanced noninvasive technique to facilitate delivery of therapeutics into the skin [63]. These properties can be engineered to make them suitable for specific biomedical applications. Some studies showed that the hydrocortisone-loaded polymeric NPs 


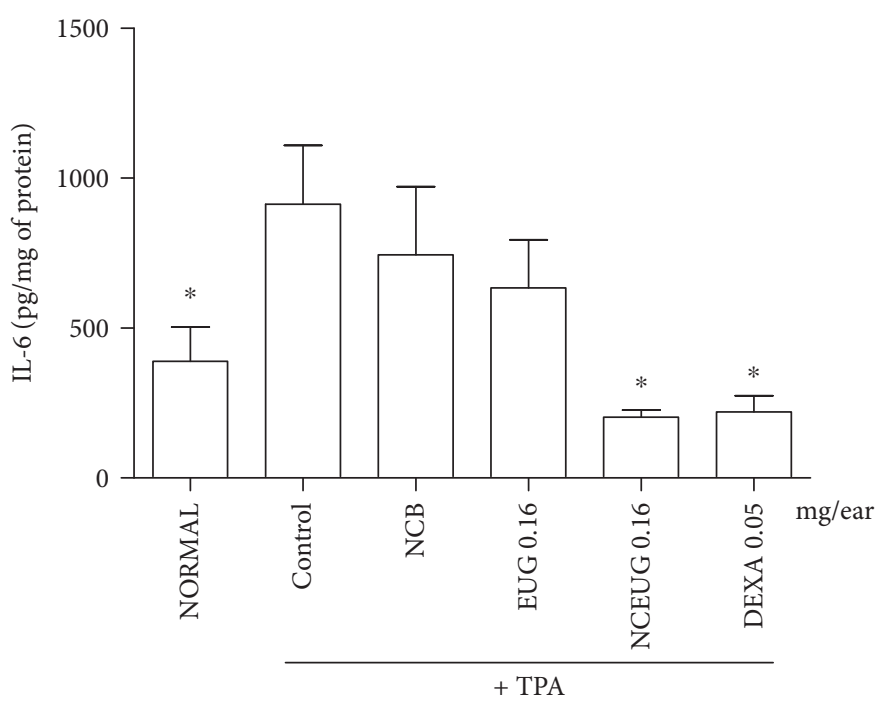

(a)

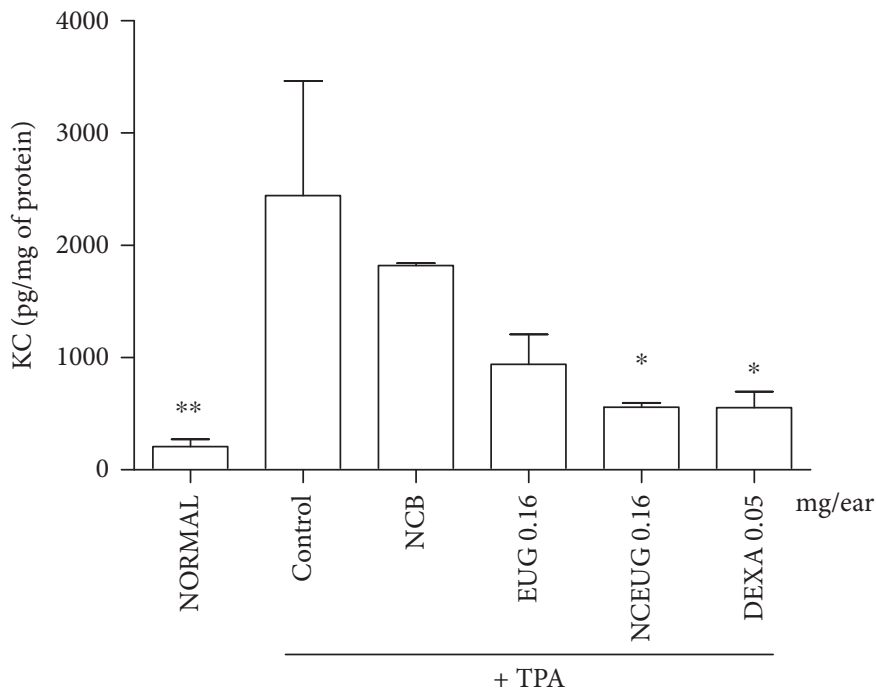

(b)

Figure 10: The effect of NCEUG from EUG and NCEUG on IL-6 (a) and KC (b) levels in ear tissue homogenates induced by TPA in mice. Swiss mice (25 to $30 \mathrm{~g}$ ) were treated topically with EUG or NCEUG (0.04, 0.08, and $0.16 \mathrm{mg} /$ ear), NCB (blank formulations), dexamethasone (DEXA; $0.05 \mathrm{mg} / \mathrm{ear})$, or acetone (vehicle control) with topical application of TPA $(2.5 \mu \mathrm{g} / \mathrm{ear})$ on the surface of the left ear of mice. Values represent mean \pm SEM from 8 animals per group. *vs control group; $p<0.05$ (ANOVA and Dunnett's test).

were more efficient in alleviating the signs and symptoms of dermatosis in mice compared to a hydrocortisone cream of equivalent and higher concentrations [64, 65].

\section{Conclusion}

The present study showed that EUG, a bioactive terpene present in essential oils of medicinal plants, inhibited the ROS production in human neutrophil, but it was toxic in human keratinocyte and did not interfere with ear edema induced by TPA. However, the nanoencapsulation of EUG (NCEUG) prevented its cytotoxicity in keratinocytes and reduced ear thickness of mice reducing the MPO activity and the concentrations of IL- 6 and KC (CXCL 1). Together, these results showed that NCEUG promoted a reduction in cytotoxicity of EUG and improved its anti-inflammatory effect. However, further studies are necessary to elucidate the antioxidant and anti-inflammatory mechanisms of action in order to determine their potential in the treatment of topic diseases, such as contact dermatitis.

\section{Data Availability}

All other data arising from this study are contained within the manuscript file.

\section{Conflicts of Interest}

The authors declare that there are no competing interests. 


\section{Acknowledgments}

This work was supported by Coordenação de Aperfeiçoamento de Pessoal de Nível Superior (CAPES, Brazil) and Fundação Cearense de Apoio ao Desenvolvimento Científico e Tecnológico (FUNCAP, Brazil).

\section{References}

[1] T. L. Diepgen and P. J. Coenrads, "The epidemiology of occupational contact dermatitis," in Handbook of Occupational Dermatology, L. Kanerva, P. Elsner, J. E. Wahlberg, and H. I. Maibach, Eds., pp. 3-16, Springer, Berlin, Heidelberg, 2000.

[2] J. M. Lachapelle and L. Marot, "Histopathological and immunohistopathological features of irritant and allergic contact dermatitis," in Contact Dermatitis, J. Johansen, P. Frosch, and J. P. Lepoittevin, Eds., pp. 167-176, Springer, Berlin, Heidelberg, 2011.

[3] E. Corsini and C. L. Galli, "Cytokines and irritant contact dermatitis," Toxicology Letters, vol. 102-103, pp. 277-282, 1998.

[4] C. M. Willis, L. Reiche, and J. D. Wilkinson, "Immunocytochemical demonstration of reduced $\mathrm{Cu}, \mathrm{Zn}$-superoxide dismutase levels following topical application of dithranol and sodium lauryl sulphate: an indication of the role of oxidative stress in acute irritant contact dermatitis," European Journal of Dermatology, vol. 1, pp. 8-12, 1998.

[5] H. Ji and X. K. Li, "Oxidative stress in atopic dermatitis," Oxidative Medicine and Cellular Longevity, vol. 2016, Article ID 2721469, 8 pages, 2016.

[6] S. Kaur, M. Zilmer, M. Eisen, T. Kullisaar, A. Rehema, and T. Vihalemm, "Patients with allergic and irritant contact dermatitis are characterized by striking change of iron and oxidized glutathione status in nonlesional area of the skin," Journal of Investigative Dermatology, vol. 116, no. 6, pp. 886890, 2001.

[7] A. Mantovani, M. A. Cassatella, C. Costantini, and S. Jaillon, "Neutrophils in the activation and regulation of innate and adaptive immunity," Nature Reviews Immunology, vol. 11, no. 8, pp. 519-531, 2011.

[8] M. Mittal, M. R. Siddiqui, K. Tran, S. P. Reddy, and A. B. Malik, "Reactive oxygen species in inflammation and tissue injury," Antioxidants \& Redox Signaling, vol. 20, no. 7, pp. 1126-1167, 2014.

[9] D. E. Cohen and N. Heidary, "Treatment of irritant and allergic contact dermatitis," Dermatologic Therapy, vol. 17, no. 4, pp. 334-340, 2004.

[10] J. G. Xu, T. Liu, Q. P. Hu, and X. M. Cao, "Chemical composition, antibacterial properties and mechanism of action of essential oil from clove buds against Staphylococcus aureus," Molecules, vol. 21, no. 9, pp. 1194-1206, 2016.

[11] F. Chami, N. Chami, S. Bennis, T. Bouchikhi, and A. Remmal, "Oregano and clove essential oils induce surface alteration of Saccharomyces cerevisiae," Phytotherapy Research, vol. 19, no. 5, pp. 405-408, 2005.

[12] C. W. Gayoso, E. O. Lima, V. T. Olivera et al., "Sensitivity of fungi isolated from onychomycosis to Eugenia cariophyllata essential oil and eugenol," Fitoterapia, vol. 76, pp. 247-249, 2005.

[13] H. M. Kim, E. H. Lee, S. H. Hong et al., "Effect of Syzygium aromaticum extract on immediate hypersensitivity in rats," Journal of Ethnopharmacology, vol. 60, no. 2, pp. 125-131, 1998.
[14] M. F. P. Corrêa, G. O. Melo, and S. S. Costa, "Substâncias de origem vegetal potencialmente úteis na terapia da Asma," Revista Brasileira de Farmacognosia, vol. 18, pp. 785-797, 2008.

[15] C. Pan and Z. Dong, "Antiasthmatic effects of eugenol in a mouse model of allergic asthma by regulation of vitamin D3 upregulated protein $1 / \mathrm{NF}-\kappa \mathrm{B}$ pathway," Inflammation, vol. 38, no. 4, pp. 1385-1393, 2015.

[16] K. Mnafgui, R. Hajji, F. Derbali et al., "Anti-inflammatory, antithrombotic and cardiac remodeling preventive effects of eugenol in isoproterenol-induced myocardial infarction in Wistar rat," Cardiovascular Toxicology, vol. 16, no. 4, pp. 336-344, 2016.

[17] Z. Yao, W. Namkung, E. A. Ko, J. Park, L. Tradtrantip, and A. S. Verkman, "Fractionation of a herbal antidiarrheal medicine reveals eugenol as an inhibitor of $\mathrm{Ca}^{2+}$-activated $\mathrm{Cl}^{-}$channel TMEM16A," PLoS One, vol. 7, no. 5, article e38030, 2012.

[18] B. Yogalakshmi, P. Viswanathan, and C. V. Anuradha, "Investigation of antioxidant, anti-inflammatory and DNAprotective properties of eugenol in thioacetamide-induced liver injury in rats," Toxicology, vol. 268, no. 3, pp. 204212, 2010.

[19] A. N. Daniel, S. M. Sartoretto, G. Schmidt, S. M. CaparrozAssef, C. A. Bersani-Amado, and C. RKN, "Anti-inflammatory and antinociceptive activities of eugenol essential oil in experimental animal models," Revista Brasileira de Farmacognosia, vol. 19, no. 1b, pp. 212-217, 2009.

[20] S. S. Kim, O. J. Oh, H. Y. Min et al., "Eugenol suppresses cyclooxygenase-2 expression in lipopolysaccharide-stimulated mouse macrophage RAW264.7 cells," Life Sciences, vol. 73, pp. 337-348, 2003.

[21] H. Raghavenra, B. T. Diwakr, B. R. Lokesh, and K. A. Naidu, "Eugenol-the active principle from cloves inhibits 5lipoxygenase activity and leukotriene-C4 in human PMNL cells," Prostaglandins, Leukotrienes and Essential Fatty Acids, vol. 74, no. 1, pp. 23-27, 2006.

[22] T. F. Bachiega, J. P. Sousa, J. K. Bastos, and J. M. Sforcin, "Clove and eugenol in noncytotoxic concentrations exert immunomodulatory/anti-inflammatory action on cytokine production by murine macrophages," Journal of Pharmacy and Pharmacology, vol. 64, no. 4, pp. 610-616, 2012.

[23] S. Fireman, O. Toledano, K. Neimann, N. Loboda, and N. Dayan, "A look at emerging delivery systems for topical drug products," Dermatologic Therapy, vol. 24, no. 5, pp. 477-488, 2011.

[24] R. V. Contri, L. A. Frank, M. Kaiser, A. R. Pohlmann, and S. S. Guterres, "The use of nanoencapsulation to decrease human skin irritation caused by capsaicinoids," International Journal of Nanomedicine, vol. 9, pp. 951-962, 2014.

[25] N. M. Siqueira, R. V. Contri, K. Paese, B. RCR, A. R. Pohlman, and S. S. Guterres, "Innovative sunscreen formulation based on benzophenone-3-loaded chitosan-coated polymeric nanocapsules," Skin Pharmacology and Physiology, vol. 24, no. 3, pp. 166-174, 2011.

[26] J. Varani, P. Perone, D. M. Spahlinger et al., "Human skin in organ culture and human skin cells (keratinocytes and fibroblasts) in monolayer culture for assessment of chemically induced skin damage," Toxicologic Pathology, vol. 35, no. 5, pp. 693-701, 2007.

[27] L. A. Frank, G. Sandri, F. Dautilia et al., "Chitosan gel containing polymeric nanocapsules: a new formulation for vaginal 
drug delivery," International Journal of Nanomedicine, vol. 9, pp. 3151-3161, 2014.

[28] Y. M. Lucisano and B. Mantovani, "Lysosomal enzyme release from polymorphonuclear leukocytes induced by immunecomplexes of IgM and IgG," The Journal of Immunology, vol. 132, no. 4, pp. 2015-2020, 1984.

[29] L. M. Kabeya, A. Kanashiro, A. E. C. S. Azzolini, F. M. Soriani, L. JLC, and Y. M. Lucisano-Valim, "Inhibitory effect of eight simple coumarins on the lucigenin enhanced chemiluminescence of rabbit neutrophils," Research communications in molecular pathology and pharmacology, vol. 111, pp. 103$114,2002$.

[30] T. Mosmann, "Rapid colorimetric assay for cellular growth and survival: application to proliferation and cytotoxicity assays," Journal of Immunological Methods, vol. 65, no. 1-2, pp. 55-63, 1983.

[31] Z. Darzynkiewicz, S. Bruno, G. Del Bino et al., "Features of apoptotic cells measured by flow cytometry," Cytometry, vol. 13, no. 8, pp. 795-808, 1982.

[32] A. Boyum, "Isolation of mononuclear cells and granulocytes from human blood. Isolation of monuclear cells by one centrifugation, and of granulocytes by combining centrifugation and sedimentation at $1 \mathrm{~g}$," Scandinavian Journal of Clinical and Laboratory Investigation, vol. 21, pp. 77-89, 1968.

[33] F. S. Paula, L. M. Kabeya, A. Kanashiro et al., "Modulation of human neutrophil oxidative metabolism and degranulation by extract of Tamarindus indica L. fruit pulp," Food and Chemical Toxicology, vol. 47, no. 1, pp. 163-170, 2009.

[34] H. Fessi, F. Puisieux, J. P. Devissaguet, N. Ammoury, and S. Benita, "Nanocapsule formation by interfacial polymer deposition following solvent displacement," International Journal of Pharmaceutics, vol. 55, no. 1, pp. R1-R4, 1989.

[35] F. C. Flores, R. F. Ribeiro, A. F. Ourique, R. CMB, and C. B. Silva, "Nanostructured systems containing an essential oil: protection against volatilization," Química Nova, vol. 34, no. 6, pp. 968-972, 2011.

[36] S. M. Yun, M. H. Lee, K. J. Lee, H. O. Ku, S. W. Son, and Y. S. Joo, "Quantitative analysis of eugenol in clove extract by a validated HPLC method," Journal of AOAC International, vol. 93, no. 6, pp. 1806-1810, 2010.

[37] L. Marchal-Heussler, P. Maicent, M. Hoffman, J. Spittler, and P. Couvreur, "Antiglaucomatous activity of betaxolol chlorhydrate sorbed onto different isobutylcyanoacrylate nanoparticle preparations," International Journal of Pharmaceutics, vol. 58, no. 2, pp. 115-122, 1990.

[38] M. C. Recio, R. M. Giner, L. Uriburu et al., "In vivo activity of pseudoguaianolide sesquiterpene lactones in acute and chronic inflammation," Life Sciences, vol. 66, no. 26, pp. 25092518, 2000.

[39] L. M. De Young, J. B. Kheifets, S. J. Ballaron, and J. M. Young, "Edema and cell infiltration in the phorbol ester-treated mouse ear are temporally separate and can be differentially modulated by pharmacologic agents," Agents and Actions, vol. 26, no. 3-4, pp. 335-341, 1989.

[40] B. Safieh-Garabedian, S. Poole, A. Allchorne, J. Winter, and C. J. Woolf, "Contribution of interleukin-1 beta to the inflammation-induced increase in nerve growth factor levels and inflammatory hyperalgesia," British Journal of Pharmacology, vol. 117, pp. 1265-1275, 2005.

[41] F. Q. Cunha, M. A. Boukili, J. I. da Motta, B. B. Vargaftig, and S. H. Ferreira, "Blockade by fenspiride of endotoxin-induced neutrophil migration in the rat," European Journal of Pharmacology, vol. 238, no. 1, pp. 47-52, 1993.

[42] G. Koopman, C. P. Reutelingsperger, G. A. Kuijten, R. M. Keehnen, S. T. Pals, and M. H. Van Oers, "Annexin V for flow cytometric detection of phosphatidylserine expression on $\mathrm{B}$ cells undergoing apoptosis," Blood, vol. 84, no. 5, pp. 14151420, 1994.

[43] D. Thompson, D. Constantin-Teodosiu, K. Norbeck, B. Svensson, and P. Moldéus, "Metabolic activation of eugenol by myeloperoxidase and polymorphonuclear leukocytes," Chemical Research in Toxicology, vol. 2, no. 3, pp. 186-192, 1989.

[44] F. C. Weber, T. Németh, J. Z. Csepregi et al., "Neutrophils are required for both the sensitization and elicitation phase of contact hipersensivity," Journal of Experimental Medicine, vol. 212, no. 1, pp. 15-22, 2015.

[45] F. R. Sheppard, M. R. Kelher, E. E. Moore, N. J. McLaughlin, A. Banerjee, and C. C. Silliman, "Structural organization of the neutrophil NADPH oxidase: phosphorylation and translocation during priming and activation," Journal of Leukocyte Biology, vol. 78, no. 5, pp. 1025-1042, 2005.

[46] C. C. Winterbourn, "Biological reactivity and biomarkers of the neutrophil oxidant, hypochlorous acid," Toxicology, vol. 181-182, pp. 223-227, 2002.

[47] D. Lau, H. Mollnau, J. P. Eiserich et al., "Myeloperoxidase mediates neutrophil activation by association with CD11b/ CD18 integrins," Proceedings of the National Academy of Sciences of the United States of America, vol. 102, no. 2, pp. 431-436, 2005.

[48] S. W. Edwards, "The $\mathrm{O}_{2}^{-}$generating NADPH oxidase of phagocytes: structure and methods of detection," Methods, vol. 9, no. 3, pp. 563-577, 1996.

[49] G. L. Semenza, "Hypoxia-inducible factors: mediators of cancer progression and targets for cancer therapy," Trends in Pharmacological Sciences, vol. 33, no. 4, pp. 207-214, 2012.

[50] K. Nakai, K. Yoneda, and Y. Kubota, "Oxidative stress in allergic and irritant dermatitis: from basic research to clinical management," Recent Patents on Inflammation \& Allergy Drug Discovery, vol. 6, no. 3, pp. 202-209, 2012.

[51] F. Caldefie-Chezét, S. Walrand, C. Moinard, A. Tridon, J. Chassagne, and M. P. Vasson, "Is the neutrophil reactive oxygen species production measured by luminol and lucigenin chemiluminescence intra or extracellular? Comparison with DCFH-DA flow cytometry and cytochrome c reduction," Clinica Chimica Acta, vol. 319, no. 1, pp. 9-17, 2002.

[52] J. Baek and M. G. Lee, "Oxidative stress and antioxidant strategies in dermatology," Redox Report, vol. 21, no. 4, pp. 1-6, 2016.

[53] M. Ogata, M. Hoshi, S. Urano, and T. Endo, "Antioxidant activity of eugenol and related monomeric and dimeric compounds," Chemical and Pharmaceutical Bulletin, vol. 48, no. 10, pp. 1467-1469, 2000.

[54] M. Kalmes, A. Neumeyer, P. Rio, H. Hanenberg, E. Fritsche, and B. Blömeke, "Impact of the arylhydrocarbon receptor on eugenol- and isoeugenol-induced cell cycle arrest in human immortalized keratinocytes ( $\mathrm{HaCaT}), "$ Biological Chemistry, vol. 387, no. 9, pp. 1201-1207, 2006.

[55] M. Kalmes and B. Blömeke, "Impact of eugenol and isoeugenol on AhR translocation, target gene expression, and proliferation in human HaCaT keratinocytes," Journal of Toxicology 
and Environmental Health. Part A, vol. 75, no. 8-10, pp. 478491, 2012.

[56] A. R. Pohlmann, F. N. Fonseca, K. Paese et al., "Poly ( $\epsilon$-caprolactone) microcapsules and nanocapsules in drug delivery," Expert Opinion on Drug Delivery, vol. 10, no. 5, pp. 623-638, 2013.

[57] D. SON, N. Yirang, C. Wan-Seob et al., "Differentiation of skin sensitizers from irritant chemicals by interleukin- $1 \alpha$ and macrophage inflammatory protein-2 in murine keratinocytes," Toxicology Letters, vol. 216, no. 1, pp. 65-71, 2013.

[58] K. Paese, A. Jäger, F. S. Poletto et al., "Semisolid formulation containing a nanoencapsulated sunscreen: effectiveness, in vitro photostability and immune response," Journal of Biomedical Nanotechnology, vol. 5, no. 3, pp. 240-246, 2009.

[59] M. C. Fontana, J. F. P. Rezer, K. Coradini, D. B. R. Leal, and R. C. R. Beck, "Improved efficacy in the treatment of contact dermatitis in rats by a dermatological nanomedicine containing clobetasol propionate," European Journal of Pharmaceutics and Biopharmaceutics, vol. 79, no. 2, pp. 241-249, 2011.

[60] T. Dohi, H. Terada, S. Anamura, H. Okamoto, and A. Tsujimoto, "The anti-inflammatory effects of phenolic dental medicaments as determined by mouse ear edema assay," The Japanese Journal of Pharmacology, vol. 49, no. 4, pp. 535-539, 1989.

[61] B. Biruss and C. Valenta, "Skin permeation of different steroid hormones from polymeric coated liposomal formulations," European Journal of Pharmaceutics and Biopharmaceutics, vol. 62, no. 2, pp. 210-219, 2006.

[62] S. Kuchler, M. R. Radowski, T. Blaschke et al., "Nanoparticles for skin penetration enhancement-a comparison of a dendritic core-multishell-nanotransporter and solid lipid nanoparticles," European Journal of Pharmaceutics and Biopharmaceutics, vol. 71, no. 2, pp. 243-250, 2009.

[63] J. Lademann, H. Richter, A. Teichmann et al., "Nanoparticles an efficient carrier for drug delivery into the hair follicles," European Journal of Pharmaceutics and Biopharmaceutics, vol. 66, no. 2, pp. 159-164, 2007.

[64] Z. Hussain, H. Katas, M. C. I. M. Amin, E. Kumolosasi, and S. Sahudin, "Antidermatitic perspective of hydrocortisone as chitosan nanocarriers: an ex vivo and in vivo assessment using an NC/Nga mouse model," Journal of Pharmaceutical Sciences, vol. 102, no. 3, pp. 1063-1075, 2013.

[65] Z. Hussain, H. Katas, A. MCIM, and E. Kumolosasi, "Efficient immuno-modulation of $\mathrm{T}_{\mathrm{H} 1} / \mathrm{T}_{\mathrm{H} 2}$ biomarkers in 2,4-dinitrofluorobenzene-induced atopic dermatitis: nanocarriermediated transcutaneous co-delivery of anti-inflammatory and antioxidant drugs," PLoS One, vol. 9, no. 11, article e113143, 2014. 


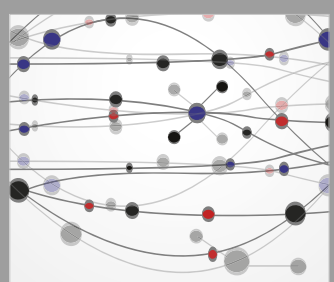

The Scientific World Journal
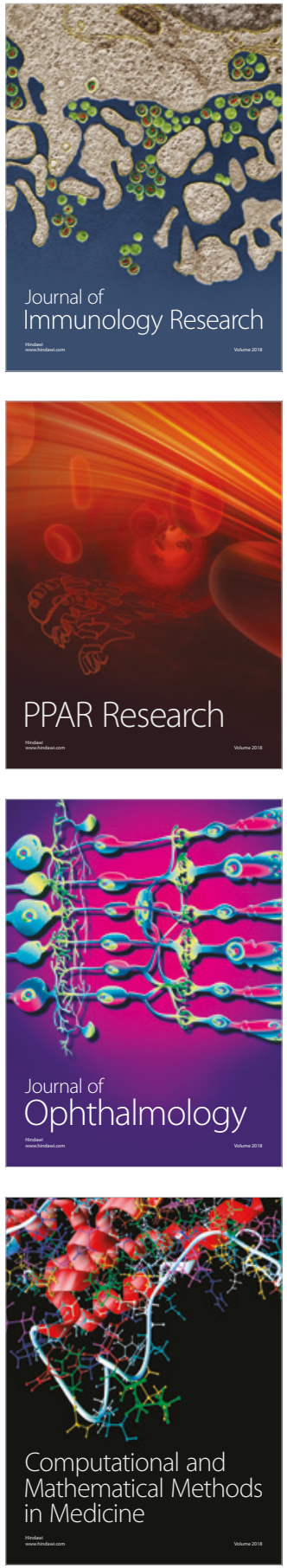

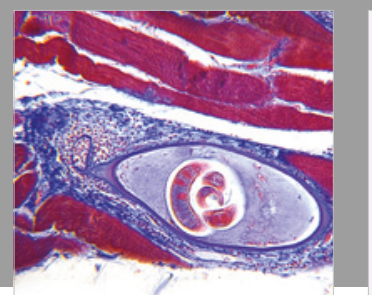

Gastroenterology Research and Practice

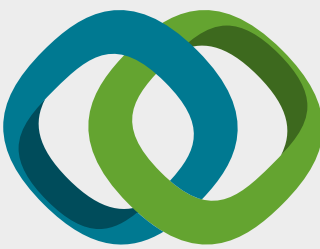

\section{Hindawi}

Submit your manuscripts at

www.hindawi.com
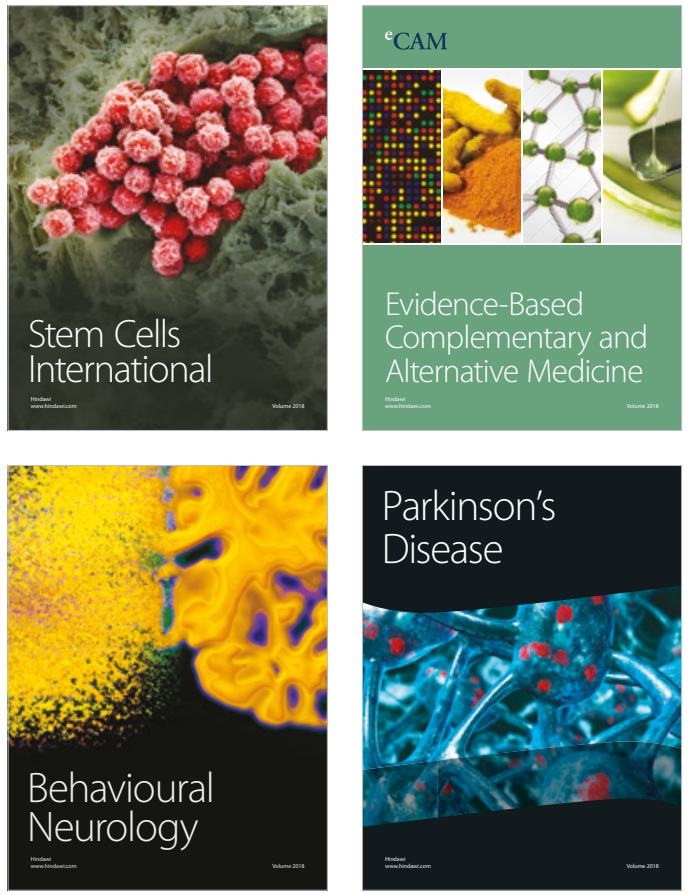

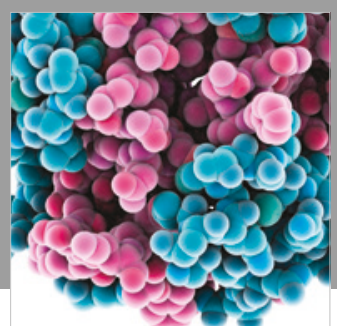

ournal of

Diabetes Research

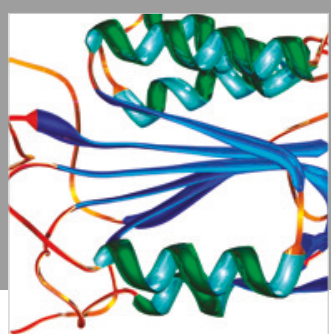

Disease Markers
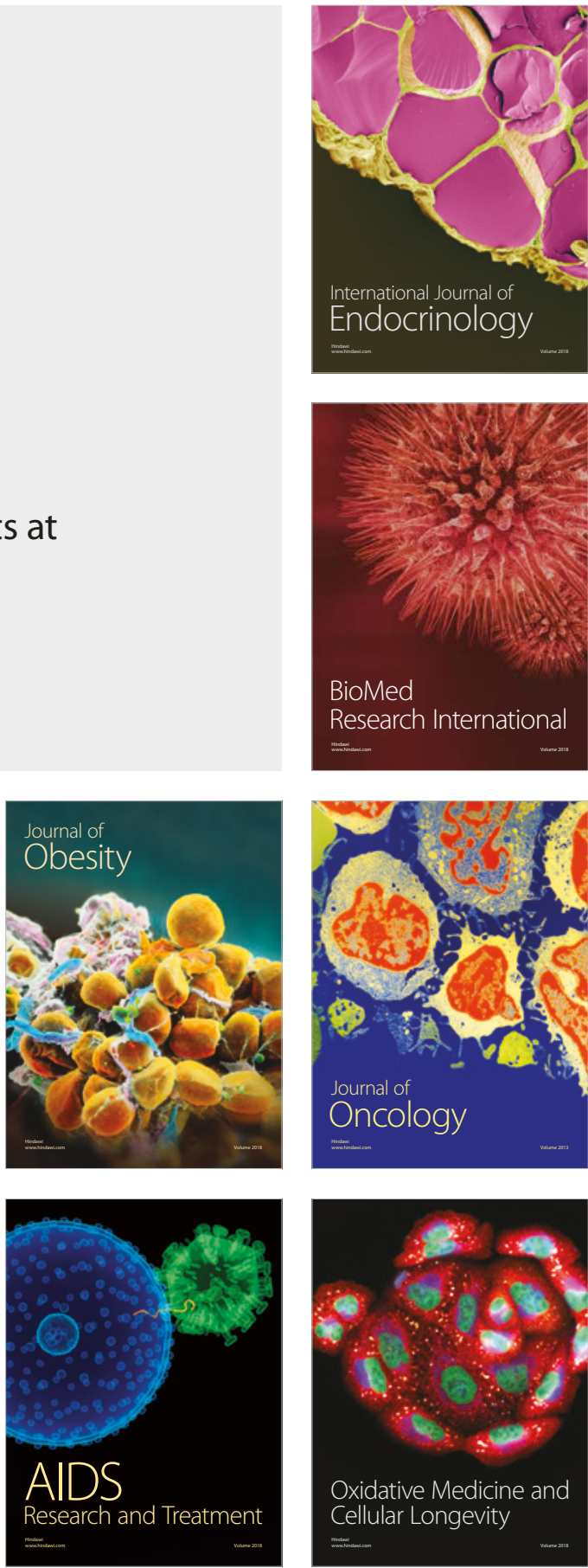